\title{
THE INFLUENCE OF MICROWAVE COOKING ON THE NUTRITIONAL COMPOSITION AND ANTIOXIDANT ACTIVITY OF THE UNDERUTILIZED PERAH SEED
}

\author{
Khu S. Li ${ }^{1}$, Abbas Ali ${ }^{\circledR}$, Ida I. Muhammad ${ }^{1}$ \\ ${ }^{1}$ Department of Bioprocess and Polymer Engineering, University of Technology, Malaysia \\ 81310 Johor Bahru, Johor, Malaysia \\ ${ }^{2}$ Department of Chemistry, Rajshahi University of Engineering and Technology \\ Rajshahi 6204, Bangladesh
}

\begin{abstract}
Background. Perah seed is one of the most underutilized oilseeds, containing high nutritional values and high percentage of $\alpha$-linoleneic acid, which may have a high potential in food and pharmaceutical applications. The main objective of this study was to evaluate the influence of microwave (MW) cooking on the proximate composition and antioxidant activity of perah seeds.

Material and methods. In this study, the proximate composition and amygdalin concentration of MW irradiated perah seeds were determined. The total phenolic content (TPC), Maillard reaction products (MRPs) and antioxidant activity of methanol (PME), 70\% methanol in water (PMW), ethanol (PEE), 70\% ethanol in water (PEW) extracts and methanol extract of oil (PMO) were evaluated during MW cooking. The antioxidant activity was evaluated using multiple assays, namely DPPH radical scavenging activity, $\beta$-Carotene bleaching assay, and reducing power.

Results. Microwave cooking did not significantly increase crude lipid and carbohydrate content, and the amounts of other nutrients such as ash, crude protein and fibre remained almost unchanged. As evaluated by HPLC, the amygdalin concentration in the seeds was reduced by MW cooking. The TPC, MRP and antioxidant activity of the solvent extracts of perah seeds increased significantly with increasing roasting time. Of all the extracts, PMW at all MW cooking times displayed the highest antioxidant effectiveness. However, thermal treatment significantly reduced the antioxidant properties of PMO. The values for TPC, MRP and antioxidant effectiveness of the samples were ranked in the following order: $\mathrm{PMW}>\mathrm{PEW}>\mathrm{PME}>\mathrm{PEE}>$ $\mathrm{PMO}$, in both control and microwaved samples.

Conclusions. In determining the overall quality of the products, MW cooking time was found to be a critical factor. Solubilization of phenolic compounds and formation of MRPs during MW cooking could have caused the increase in antioxidant activity of the perah seeds.
\end{abstract}

Keywords: nutritional composition, antioxidant activity, microwave cooking and perah seed

\section{INTRODUCTION}

Perah (Elateriospermum tapos) seed is a type of seed that can be easily grown and is found in abundance, especially on the east coast of Malaysia and in southern
Thailand. The perah fruits are about $2-2.5$ in long, oblong, buff in colour and suffused pink on the exposed side, hanging singly on a stalk $1-6$ in long. The perah

『radwiya44@yahoo.com 
seeds are about 1.75 in long and shiny and brown in colour, with a faint ridge on each side (Corner, 1989). Amygdalin, a type of cyanogenic glycoside, has been detected in perah seeds. The amount of amygdalin was much higher in fresh seeds $(660 \mathrm{ppm})$ than cooked seeds $(100 \mathrm{ppm})$ and fermented seeds $(25 \mathrm{ppm})$. It is clearly shown that heat and fermentation can reduce the amount of amygdalin in the edible seeds (Ngamriabsakul and Kommen, 2009). Inhabitants of this region consume perah seeds in cooked form (boiled or roasted; Yong and Salimon, 2006). Yong and Salimon (2006) stated that perah seed oil has the potential to be developed for the food, pharmaceutical and oleochemical industries.

The effects of various processing methods used to prepare oilseeds for human consumption are an important subject of investigation. Roasting is a heat treatment used to induce the development of the typical colour, taste and flavour; it also changes the chemical composition, modifying nutritional value and shelf life (Ozdemir and Devres, 2000). However, microwave cooking is a fairly recent development, which is gaining momentum in households and especially in restaurants for its speed, convenience and efficiency compared to conventional heating methods (Behera et al., 2004). Tenyang et al. (2017) stated that the proximate composition of foods was significantly affected during roasted. Jogihalli et al. (2017) concluded that a significant increase in total phenolic content and antioxidant activity was observed after roasting chickpea seeds. Ali et al. (2016a) stated that antioxidant activity increased with increasing roasting time and extract concentration of groundnut seeds. Baba et al. (2016) reported that microwave cooking significantly affected the antioxidant and anti-cancerous activities of barley. Wani et al. (2016) found that TPC and antioxidant activity of arrowhead was enhanced by microwave cooking. Mariod et al. (2012) stated that microwave cooking improves the nutritional value of safflower seeds by increasing total, and some individual, amino acids. To our knowledge, there has never been a study on the effect of microwave cooking on the anti-oxidative activity and chemical composition of seeds of the perah cultivar grown in Malaysia. The present work was therefore carried out to investigate the effect of microwave cooking on the nutritional composition, amygdalin concentration and antioxidant activity of the underutilized perah seed.

\section{MATERIAL AND METHODS}

\section{Materials}

Freshly harvested and dried perah seeds (500 g, Elateriospermum tapos Blume) were purchased from the local market at Benta, Pahang, in August 2014. Mature, healthy seeds were sorted, and stored at $4^{\circ} \mathrm{C}$ in sealed plastic bags. The various chemicals and reagents used were of analytical grade and were purchased from J.T. Baker (Phillipsburg, USA), Merck (Darmstadt, Germany) or Sigma Chemical Co. (St. Louis, MO, USA).

\section{Roasting protocol}

A domestic-size microwave oven ((Model NNST65IM, Panasonic Co. Ltd., China) at $2450 \mathrm{MHz}$, with a power output of $900 \mathrm{~W}$, was used. The perah seeds were arranged in a single layer in a Pyrex petri dish $(12 \mathrm{~cm}$ diameter) and heated at a medium power setting, for different periods $(1,2$, and $3 \mathrm{~min})$ after covering the dish based on trial results. The final seed temperatures at various MW cooking times were measured by inserting a calibrated thermocouple (Model HI 9043, Hanna Instruments Ltd., Bedfordshire, UK) into the seeds immediately after removal from the oven. After MW cooking, the seeds were allowed to cool to ambient temperature. The seed coats were manually removed from both control and roasted seeds, and the seeds were ground to fine powder.

\section{Proximate analysis of perah seeds}

The moisture content was determined using a moisture content analyzer (FD-620, Kett, CA, USA). The crude lipid, ash and fibre contents were determined following the standard methods of the Association of Official Analytical Chemists (AOAC, 1990). The organic nitrogen content was quantified using the micro Kjeldahl method, and an estimate of the crude protein content was estimated by multiplying the organic nitrogen content by a factor of 6.25 (AOAC, 1990). Total carbohydrate content was calculated by difference. Energy was calculated using energy conversion factors of 4.0, 4.0 and $9.0 \mathrm{kcal} / 100 \mathrm{~g}$ for protein, carbohydrate and fat respectively. 


\section{Amygdalin concentration by HPLC}

Chromatographic determination of amygdalin was carried out on a $0.2 \mathrm{~g}$ perah seed sample, according to the method described elsewhere (Dicenta et al., 2002; Ngamriabsakul and Kommen, 2009). The sample was extracted with $10 \mathrm{ml}$ of methanol for $12 \mathrm{~h}$ at room temperature in the presence of $0.1 \mathrm{~g}$ of polyvinylpolypyrrolidone. Chromatographic separation was performed by HPLC system (PerkinElmer Series 200, PerkinElmer Life and Analytical Sciences, Connecticut, USA) furnished with a packed RP-18 column (250 $\times 4 \mathrm{~mm}$ ) and a detector under UV at $218 \mathrm{~nm}$ using acetonitrile:water (20:80) as mobile phase at a flow rate of $0.8 \mathrm{ml} / \mathrm{min}$. The cyanogenic glycoside was identified by comparing the retention time with that of the authentic accepted standards, amygdalin (D-mandelonitrile$-\beta$-D-gentiobioside). Quantification was based on an external standard method, where the calibration curve ranged from 2 to $15 \mathrm{mg} / 1$ of the reference compound, amygdalin.

\section{Solvent extraction for antioxidant evaluation}

The Soxhlet method, as described by AOAC (1990), was used to extract oil with $\mathrm{n}$-hexane for $8 \mathrm{~h}$. After extraction, the oil in the hexane mixture was filtered, followed by evaporation of the solvent in vacuo at $45^{\circ} \mathrm{C}$. Extraction was carried out separately with methanol (PME), 70\% methanol in water (PMW), ethanol (PEE), and $70 \%$ ethanol in water (PEW) from the de-fatted seeds left after extraction with n-hexane, using a shaking incubator (ST-250D, SASTEC, Selangor, Malaysia) at room temperature for $24 \mathrm{~h}$. The solvent was removed from the extract by the same procedure as described earlier. The oil and other solvent extracts were weighed to calculate the yield and stored in glass containers at $-16^{\circ} \mathrm{C}$ prior to further analysis.

\section{Heat treatment of oil samples}

The cooked or control oil samples $(80 \mathrm{~g})$ were weighed into $100 \mathrm{ml}$ glass beakers and placed in an electric oven at $170^{\circ} \mathrm{C}$, in order to accelerate the lipid oxidation and thermal degradation. Oil samples were extracted at intervals of $0,4,8$, and $12 \mathrm{~h}$ and flushed with nitrogen, covered with parafilm and kept at $-16^{\circ} \mathrm{C}$ for further analysis.

\section{Methanolic extract of oil sample}

Methanolic extracts of the oil (PMO) sample were obtained after heat treatment, and prepared according to the method of Durmaz and Gökmen (2011). One gram of oil sample and $1 \mathrm{ml} \mathrm{70 \%} \mathrm{methanol} \mathrm{were} \mathrm{mixed} \mathrm{in}$ an Eppendorf tube and agitated with a vortex mixer for $1 \mathrm{~min}$. Samples were centrifuged at $3000 \mathrm{rpm}$ for $5 \mathrm{~min}$ and the upper methanolic phase was extracted. One millilitre of fresh $70 \%$ methanol was added to the extraction. This was repeated three times, upper phases were combined and washed with three portions of $2 \mathrm{~mL}$ of $\mathrm{n}$-hexane to remove oil residues. The final methanolic solution was diluted to achieve the desired concentration for antioxidant evaluation.

\section{Antioxidant activity assay \\ Total phenolic content (TPC). The TPC of the sam-} ple was determined using the method of Gutfinger (1981). The sample $(1 \mathrm{~mL}, 1 \mathrm{mg} / \mathrm{ml})$ was mixed with $1 \mathrm{ml}$ of $50 \%$ Folin-Ciocalteu reagent and $1 \mathrm{ml}$ of $2 \%$ $\mathrm{Na}_{2} \mathrm{CO}_{3}$, and centrifuged at $13400 \times \mathrm{g}$ for $5 \mathrm{~min}$. The absorbance of the upper phase was measured using a spectrophotometer (Jenway 7305, Spectrophotometer, Scientific Instrument Services, NJ, USA) at 750 $\mathrm{nm}$ after 30 min incubation at room temperature. Tannic acid was used as the reference standard, and the results were expressed as mg tannic acid equivalents $\mathrm{TAE} / \mathrm{g}$ defatted extract or mg TAE/g oil.

DPPH (1-diphenyl-2-picrylhydrazyl) radical scavenging activity. The radical scavenging activity was determined following the method of Negro et al. (2003). One millilitre of sample solution was thoroughly mixed with $4 \mathrm{ml}$ of DPPH $(0.1 \mathrm{mmol} / \mathrm{l})$ solution, and allowed to stand for $30 \mathrm{~min}$ in the dark. The control solution contained equivalent $70 \%$ methanol, instead of the sample solution. The absorbance was computed at $517 \mathrm{~nm}$ against a blank control without the sample. DPPH free radical-scavenging activity was calculated according to the following equation:

$$
\begin{gathered}
\text { DPPH radical-scavenging activity, } \%= \\
{\left[\left(\mathrm{A}_{\text {control }}-\mathrm{A}_{\text {sample }}\right) / \mathrm{A}_{\text {control }}\right] \times 100}
\end{gathered}
$$

$\boldsymbol{\beta}$-Carotene bleaching assay. The $\beta$-carotene bleaching assay was performed as described by Durmaz and Alpaslan (2007). In brief, a $2 \mathrm{ml}$ solution of $\beta$-carotene 
in chloroform $(0.2 \mathrm{mg} / \mathrm{ml})$ was added to $40 \mathrm{mg}$ of linoleic acid and $400 \mathrm{mg}$ of Tween-20. The chloroform was evaporated in vacuo at $45^{\circ} \mathrm{C}$ for $4 \mathrm{~min}$, and 100 $\mathrm{ml}$ distilled water was added with vigorous agitation to form an emulsion. $3 \mathrm{ml}$ of this emulsion was added to each tube containing $50 \mu 1$ samples of oil. The tubes were incubated in a water bath at $50^{\circ} \mathrm{C}$ for $120 \mathrm{~min}$. Absorbance was measured at $470 \mathrm{~nm}$, immediately, against a blank consisting of the emulsion without $\beta$-carotene. Antioxidant activity (AA), which was expressed as the delay in the bleaching of $\beta$-carotene, was determined using the following formula: $\mathrm{AA}=$ $100\left[1-\left(\mathrm{A}_{0}-\mathrm{A}_{\mathrm{t}}\right) /\left(\mathrm{A}_{0}^{0}-\mathrm{A}_{\mathrm{t}}^{0}\right)\right.$; where $\mathrm{A}_{0}$ and $\mathrm{A}_{0}^{0}$ represent the absorbance values measured at zero time of incubation for the test sample and the control respectively. The $\mathrm{A}_{t}$ and $\mathrm{A}_{\mathrm{t}}^{0}$ represent the absorbance measured in the test sample and the control respectively, after incubation for $120 \mathrm{~min}$.

Reducing power. The reducing power of the extracts was determined according to the method of Atmani et al. (2009). One millilitre of sample $(1 \mathrm{mg} / \mathrm{ml}), 2 \mathrm{ml}$ phosphate buffer $(0.2 \mathrm{M}, \mathrm{pH} 6.6)$, and $2.5 \mathrm{ml}$ potassium ferricyanide $(1 \%, \mathrm{w} / \mathrm{v})$ were mixed and incubated at $50^{\circ} \mathrm{C}$ for $20 \mathrm{~min}$. Trichloroacetic acid $(2.5 \mathrm{ml}, 10 \%)$ was added to the mixture. A portion of the solution $(2.5 \mathrm{ml})$ was mixed with distilled water $(2.5 \mathrm{ml})$ and ferric chloride $(0.5 \mathrm{ml}, 0.1 \%)$, and then the absorbance was measured at $700 \mathrm{~nm}$ at a reaction time of $30 \mathrm{~min}$.

Maillard reaction products (MRPs). The amount of MRPs was evaluated according to the non-enzymatic browning measurement (Kim et al., 2011). The sample was diluted to $1: 100$ with distilled water to give absorbance signals on a scale. The samples were allowed to stand for $1 \mathrm{~h}$ and filtered using a $0.45 \mu \mathrm{m}$ filter, prior to measuring optical density using a spectrophotometer (Jenway 7305, Scientific Instrument Services, NJ, USA) at $420 \mathrm{~nm}$.

\section{Statistical analysis}

All data were expressed as the mean and standard deviation (SD) and were subjected to one way analysis of variance (ANOVA). Mean values were compared at $p<0.05$ significant level by Duncan's multiple range test using IBM SPSS 22 statistics.

\section{RESULTS AND DISCUSSION}

\section{Changes in proximate composition}

Microwave cooking had a remarkable effect on the levels of moisture in all the samples. As shown in Table 1, with increasing MW cooking time, the moisture content of perah seeds was found to decrease. The results

Table 1. Changes in proximate composition of perah seeds during microwave cooking

\begin{tabular}{lrrrr}
\hline \multicolumn{1}{c}{ Parameter } & \multicolumn{4}{c}{ Microwave cooking, min } \\
\cline { 2 - 5 } & 0 & 1 & 2 & 3 \\
\hline Moisture, \% & $18.16 \pm 0.46^{\mathrm{c}}$ & $18.06 \pm 0.33^{\mathrm{c}}$ & $16.19 \pm 0.50^{\mathrm{b}}$ & $12.16 \pm 0.37^{\mathrm{a}}$ \\
Crude lipid, \% & $33.71 \pm 0.47^{\mathrm{a}}$ & $33.89 \pm 0.42^{\mathrm{a}}$ & $34.23 \pm 0.19^{\mathrm{a}}$ & $35.62 \pm 0.37^{\mathrm{b}}$ \\
Ash, \% & $3.39 \pm 0.10^{\mathrm{a}}$ & $3.37 \pm 0.12^{\mathrm{a}}$ & $3.36 \pm 0.21^{\mathrm{a}}$ & $3.33 \pm 0.06^{\mathrm{a}}$ \\
Crude protein, \% N & $29.33 \pm 0.17^{\mathrm{a}}$ & $29.28 \pm 0.09^{\mathrm{a}}$ & $29.24 \pm 0.15^{\mathrm{a}}$ & $29.18 \pm 0.08^{\mathrm{a}}$ \\
Crude fibre, \% & $9.39 \pm 0.02^{\mathrm{a}}$ & $9.48 \pm 0.07^{\mathrm{a}}$ & $9.42 \pm 0.05^{\mathrm{a}}$ & $9.37 \pm 0.21^{\mathrm{a}}$ \\
Carbohydrate, \% & $6.03 \pm 1.14^{\mathrm{a}}$ & $5.92 \pm 0.71^{\mathrm{a}}$ & $7.57 \pm 0.23^{\mathrm{b}}$ & $10.33 \pm 0.72^{\mathrm{c}}$ \\
Energy, kcal/100 g & $444.80 \pm 0.24^{\mathrm{a}}$ & $445.84 \pm 1.66^{\mathrm{a}}$ & $455.28 \pm 1.81^{\mathrm{b}}$ & $478.66 \pm 1.79^{\mathrm{c}}$ \\
Amygdalin concentration, ppm & $139.66 \pm 0.43^{\mathrm{d}}$ & $87.95 \pm 0.23^{\mathrm{c}}$ & $85.51 \pm 0.38^{\mathrm{b}}$ & $83.72 \pm 0.45^{\mathrm{a}}$ \\
\hline
\end{tabular}

Each value in the table represents the mean of three replicates \pm SD.

Means followed by different letters in the same row of individual parameter present significant difference $(\mathrm{p}<0.05)$. 
are in agreement with the findings reported by Ali et al. (2016b) for pumpkin seeds. However, the amount of moisture in the control sample significantly reduced from $18.16 \%$ to $12.16 \%$ after 3 min MW cooking. The crude lipid content increased insignificantly for the first 2 min of MW cooking, then increased significantly with further increasing cooking time (Table 1). The sample which was microwaved for 3 min contained the highest amount $(35.62 \%)$ of crude lipid compared to the raw sample $(33.71 \%)$. The obtained results concur with previously published results by some authors (Ali et al., 2016b; Jau-Tien et al., 2016) who reported that the lipid content increased as a result of roasting the seeds. Exposure to microwave radiation decreases seed moisture content, which directly influences the amount of lipid extracted from the seeds. Moreover, MW cooking ruptures cell membranes, which enables oil to move through the permeable cell walls more easily (Takagi et al., 1999). The amounts of ash, crude protein, and fibre in MW roasted perah seed samples were found to be almost the same to those of the control sample (Table 1). The present results are in agreement with the results reported by Anjum et al. (2006) for sunflower seeds. However, the ash, crude protein and fibre content were in the range of $3.33-3.39 \%$, $29.18-29.33 \%$, and $9.37-9.48 \%$ respectively. The minor reduction in protein content may be linked to the denaturation of nitrogenous compounds during MW cooking (Jain et al., 2016). The carbohydrate and energy contents of perah seeds are reported in Table 1. Fresh perah seeds contained $6.03 \%$ carbohydrate, which increased to $10.33 \%$ after 3 min MW cooking. In fact, this value was highly dependent on the moisture, ash, protein, fat and fibre contents of the seed, since carbohydrate content was measured by difference of dry weight of seeds to them. The amount of energy in microwaved perah seedssamples was higher than control samples. The energy value of unroasted perah seeds was $444.80 \mathrm{kcal} / 100 \mathrm{~g}$, which rose to $445.84,455.28$ and $478.66 \mathrm{kcal} / 100 \mathrm{~g}$ respectively for 1-, 2- and 3-min microwaved samples. The higher energy content is a result of the higher fat content after MW cooking.

\section{Changes in amygdalin concentration}

Under chromatographic conditions, a symmetrical chromatographic peak for obtained was standard amygdaline eluted at a retention time of $1.55 \mathrm{~min}$. Changes of amygdalin concentration with MW cooking times in perah seeds are presented in Table 1. During MW cooking, perah seed samples showed a clear decrease in amygdalin concentration. This might be explained by the effect of heating and drying during the MW cooking process, which reduced the amount of amygdalin in the seeds. Amygdalin and other cyanogenic glycosides easily release the cyanide group upon hydrolysis (Dicenta et al., 2002). The amount of amygdalin significantly reduced from $139.66 \mathrm{ppm}$ in uncooked perah seeds to $83.72 \mathrm{ppm}$ in those MW cooked for 3 mins. Ngamriabsakul and Kommen (2009) also reported that heating and fermentation reduced the amount of amygdalin in perah seeds.

\section{Changes in antioxidant activity}

Microwave cooking had a significant effect on the level of TPC in all extracts; the amounts of TPC were increased by the MW cooking process (Fig. 1a and 1b). The levels of TPC in control sample were lower, ranging from $3.46 \mathrm{mg}$ TAE/g (PMO) to $6.34 \mathrm{mg} \mathrm{TAE} / \mathrm{g}$ (PMW), compared with MW roasted (at $3 \mathrm{~min}$ ) sample values that ranged from $4.52 \mathrm{mg}$ TAE/g (PMO) to $8.94 \mathrm{mg} \mathrm{TAE} / \mathrm{g}$ (PMW). After 3 min MW cooking, the samples showed a TPC of $4.52 \mathrm{mg}$ TAE/g or more: PMW (8.94 mg TAE/g) > PEW (7.54 mg TAE/g) > PME (6.42 mg TAE/g) $>$ PEE (5.70 mg TAE/g) $>$ PMO (4.52 mg TAE/g). A similar trend was found by Ali et al. (2016a) for microwaved groundnut, and by Win et al. (2011) for oven-roasted peanut. The roasting process most likely increased the TPC through the following mechanisms: roasting might partially destroy the cell structure, resulting in the release of some bound phenolic compounds, which could then become more extractable in aqueous ethanol and acetone (Zou et al., 2015). In case of PMO, TPC contents significantly $(\mathrm{p}<0.05)$ decreased with increasing heating time and reached to $3.69 \mathrm{mg}$ TAE$/ \mathrm{g}$ after $12 \mathrm{~h}$ heating of the 3 min MW cooked sample (Fig. 1b). Herchi et al. (2016) also confirmed that the heating process caused a loss of phenolic acid content in flaxseed hull oil. This might confirm that thermal treatment causes the oxidation and polymerization of phenolic compounds present in the oil. Figure 1c and 1d illustrate a significant $(\mathrm{p}<$ 0.05 ) increase in DPPH radical-scavenging effect as the MW cooking time of seeds increased. The extracts 

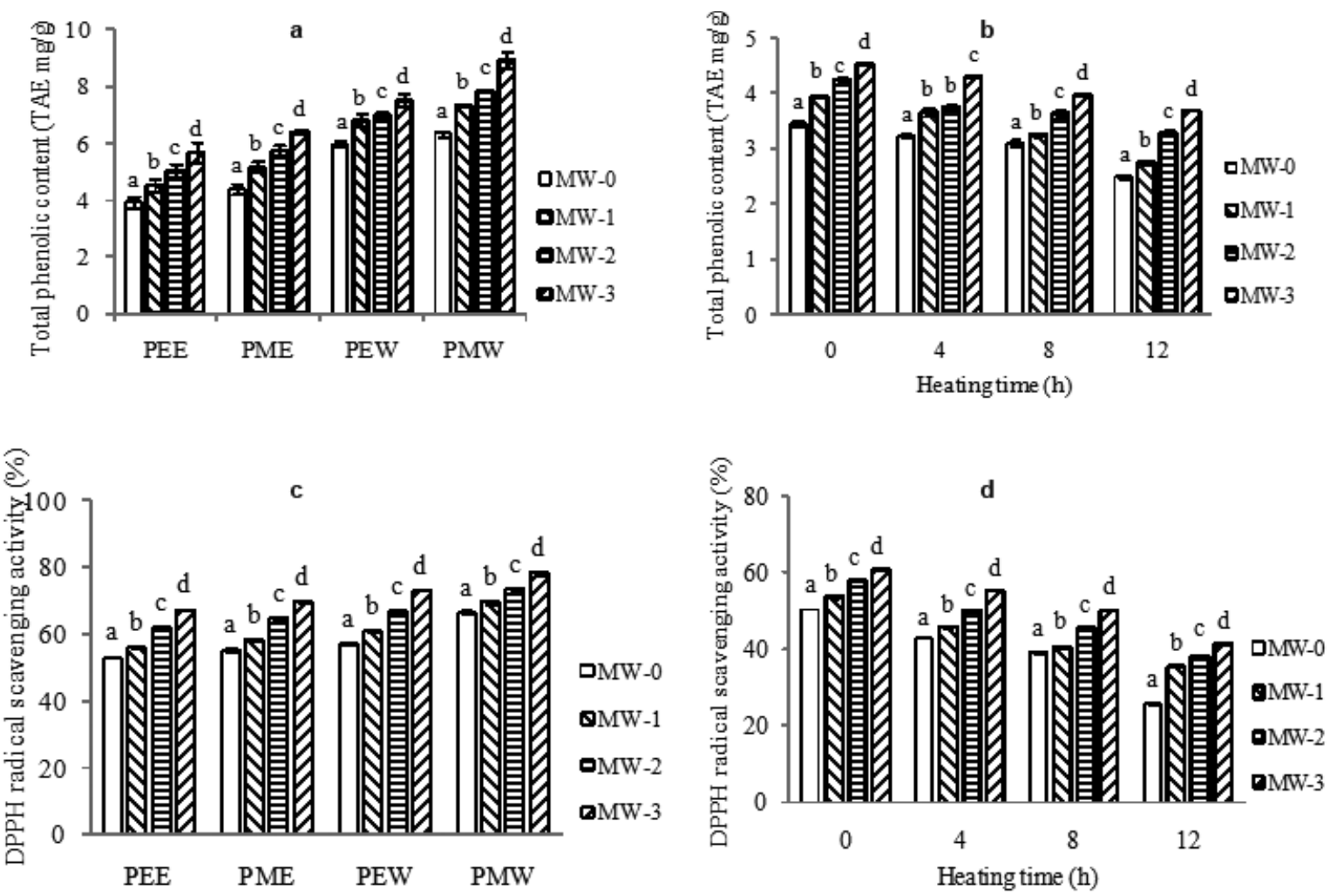

Fig. 1. Changes in total phenolic content and DPPH radical scavenging activity of PEE, PME, PEW, PMW (a and c) and PMO (b and d) extracts from control (MW-0) and microwave cooked (MW-1, microwave cooked for $1 \mathrm{~min}$; MW-2, microwave cooked for $2 \mathrm{~min}$ and MW-3, microwave cooked for $3 \mathrm{~min}$ ) perah seeds. Each value is the mean \pm standard deviation of triplicate determinations. Values in each solvent extract or heating time grouped with different letters on the bar are significantly different $(\mathrm{p}<0.05)$

PMO, PEE, PME, PEW and PMW from control seeds showed 50.48, 52.89, 55.26, 57.03 and $66.34 \%$ DPPH scavenging activity respectively, whereas the same solvent extracts from the samples MW roasted for 3 min showed $60.61,67.06,69.64,72.78$, and $78.04 \%$ activity respectively. Similar results were also reported for arrowhead by Wani et al. (2016). In this work, PMW exhibited higher DPPH scavenging activities than the other solvent extracts. In general, the methanol extract exhibited higher DPPH scavenging activity than the other solvent extracts, which might be due to a greater release of antioxidants (Baba et al., 2016). During thermal treatment, the scavenging activity of PMO decreased significantly $(\mathrm{p}<0.05)$ from 60.61 to $41.29 \%$ in the 3-min MW cooked PMO sample. Herchi et al. (2016) concluded that heated flaxseed hull oil contained fewer antioxidant compounds, which decreased the DPPH radical scavenging capacity. The scavenging action of plant constituents has been found to relate to polyphenolic compounds (Siger et al., 2008).

The assay of $\beta$-carotene bleaching is dependent on the loss of the yellow colour of $\beta$-carotene, due to its interaction with radicals created by linoleic acid oxidation in an emulsion (Nanasombat and Wimuttigosol, 2011). In the $\beta$-carotene/linoleic acid assay, the oxidation of linoleic acid generates peroxyl free radicals, which will then oxidize the highly unsaturated fatty acids, which means the presence of antioxidants will minimize the oxidation of $\beta$-carotene compounds. The $\beta$-carotene bleaching assay values of the control and MW cooked perah seeds were determined and shown in Figure 2a and 2b. Inhibition of $\beta$-carotene and linoleic acid oxidation ranged from 

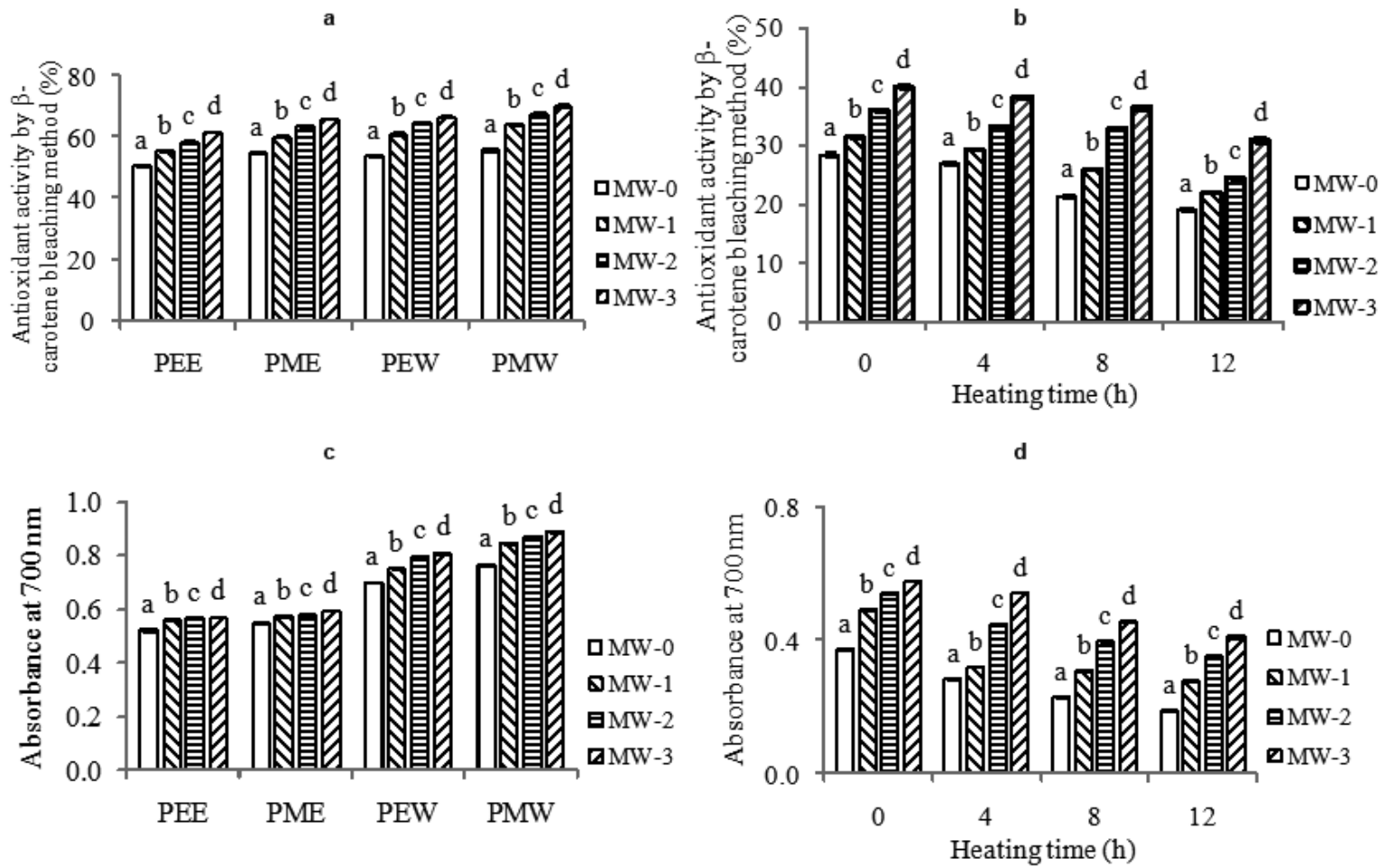

Fig. 2. Changes in antioxidant activity measured by $\beta$-carotene bleaching and reducing power of PEE, PME, PEW, PMW (a and $\mathbf{c}$ ) and PMO (b and $\mathbf{d}$ ) extracts from control (MW-0) and microwave cooked (MW-1, microwave cooked for $1 \mathrm{~min}$; MW-2, microwave cooked for $2 \mathrm{~min}$ and MW-3, microwave cooked for $3 \mathrm{~min}$ ) perah seeds. Each value is the mean \pm standard deviation of triplicate determinations. Values in each solvent extract or heating time grouped with different letters on the bar are significantly different $(\mathrm{p}<0.05)$

$28.48,50.43,54.98,53.59$ and $55.58 \%$ in the control to $39.97,61.49,65.76,66.49$ and $70.23 \%$ in the 3-min MW cooked samples of the PMO, PEE, PME, PEW and PMW extracts respectively. Durmaz et al. (2010) stated that, in the $\beta$-carotene linoleate assay, the increase in protection of $\beta$-carotene from bleaching was attenuated after 20 min of roasting but slightly decreased for the 30-min roasted sample from apricot kernel oil. Moreover, the values decreased steadily as heating time of the PMO sample increased and, after $12 \mathrm{~h}$ of heating, it reached to 30.94 for the 3-min MW cooked sample (Fig. 2b). As shown in Figure 2c and $2 \mathrm{~d}$, the MW cooking of perah seeds significantly $(\mathrm{p}<$ 0.05 ) increased reducing power. This increase in reducing power may be attributed to the production of Maillard reaction products, which contributed to antioxidant properties after cooking (Woffenden et al., 2002). During MW cooking, the absorbance at $700 \mathrm{~nm}$ increased from 0.37 to 0.58 for PMO, 0.52 to 0.57 for PEE, 0.55 to 0.59 for PME, 0.70 to 0.81 for PEW, and 0.76 to 0.89 for PMW. Microwave cooking enhanced the reducing power of arrowhead (Wani et al., 2016). Data also revealed that reducing power was roastingor heating time-dependent, and increasing the heating time at $170^{\circ} \mathrm{C}$ led to a significant decrease in reducing power, in the control and roasted sample of PMO. The PMW sample roasted for 3 min displayed the highest value, whereas the lowest value was detected in the control samples of PMO. The MRPs, which form as a consequence of intense heat treatment, are found in the molecular weight range of $<30 \mathrm{kDa}$, and they generally have strong antioxidant properties (Manzocco et al., 2000; Summa et al., 2006). In this work, nonenzymatic browning measurements were performed at $420 \mathrm{~nm}$ to evaluate the degree of roasting and MRPs in perah seeds. According to the other antioxidative 

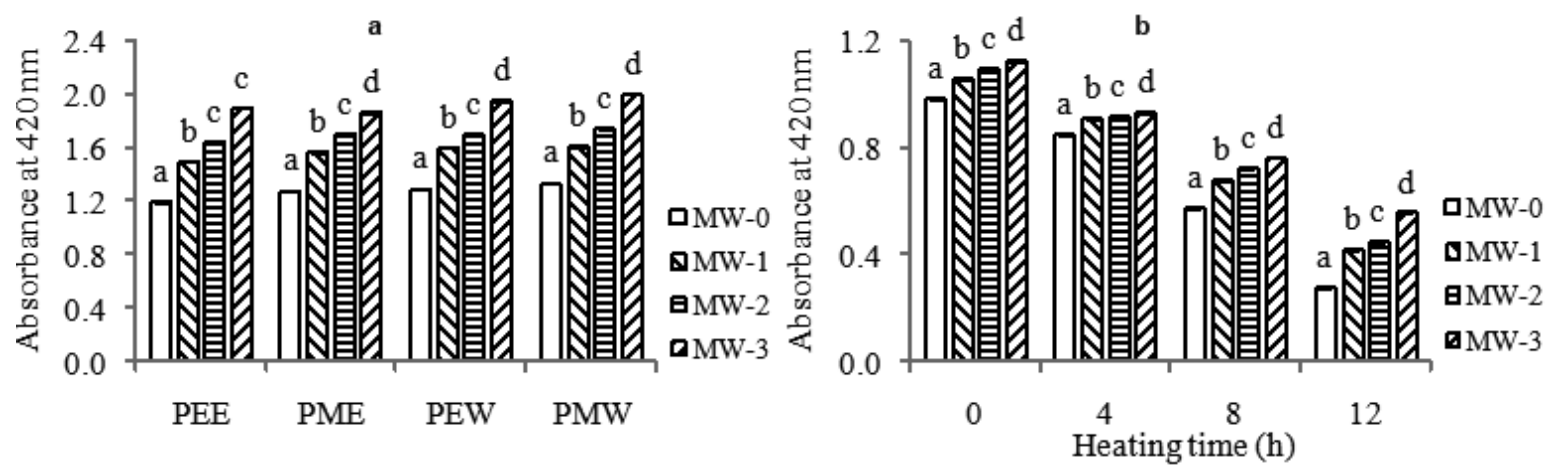

Fig. 3. Changes in Maillard reaction products of PEE, PME, PEW, PMW extracts (a) and PMO (b) extracts from control (MW-0) and microwave cooked (MW-1, microwave cooked for $1 \mathrm{~min}$; MW-2, microwave cooked for $2 \mathrm{~min}$ and MW-3, microwave cooked for $3 \mathrm{~min}$ ) perah seeds. Each value is the mean \pm standard deviation of triplicate determinations. Values in each solvent extract or heating time grouped with different letters on the bar are significantly different $(\mathrm{p}<0.05)$

assays, as stated, the MW cooking process enhanced the antioxidant activity of perah seed extracts. Nonenzymatic browning showed the same pattern under the same conditions. The values of optical density at $420 \mathrm{~nm}$ significantly $(\mathrm{p}<0.05)$ increased from 0.98 , $1.19,1.27,1.29$, and 1.33 in the uncooked control to $1.12,1.86,1.89,1.94$, and 2.00 in the $3-\min \mathrm{MW}$ cooked samples of PMO, PEE, PME, PEW and PMW respectively. Kim et al. (2011) reported that heat treatment was effective in increasing the degree of browning in small black soybean. In addition, the optical density of PMO was significantly $(\mathrm{p}<0.05)$ reduced by thermal treatment, and this decrease gradually and significantly increased with increasing heating time at $170^{\circ} \mathrm{C}$. At the end of $12 \mathrm{~h}$ of thermal treatment, the optical density in PMO reduced to 0.55 for the 3-min MW cooked sample of PMO.

\section{CONCLUSIONS}

The MW cooking process was not as effective in increasing the nutritional quality of perah seeds as was suggested by determining ash, crude protein and fibre. MW cooking substantially enhanced the TPC and antioxidant activity of the perah seed flour and in this regard, MRPs formed during the cooking process are able to contribute to antioxidant activity. Moreover, MRPs might lead to an increase in the amount of total phenolics or phenolic-like complexes that further contribute to higher absorbance readings measured by the Folin assay. The duration of microwave cooking also affected the total phenolic levels in the extracts, which led to changes in their antioxidant activities. The thermal treatment of oil at $170^{\circ} \mathrm{C}$ significantly reduced antioxidative properties. In the present study, MW cooking caused a significant reduction of the amygdalin concentration in perah seeds, which may result in the seeds being more suitable for human consumption, as uncooked seeds taste bad and can cause dizziness. The aqueous methanol extract of microwaved perah seeds are a potent source of antioxidant agents compared to other solvent extracts. Therefore, the perah seeds can be considered a good source of important bioactive constituents which are beneficial to human health.

\section{REFERENCES}

Ali, A., Islam, A., Pal, T. K. (2016a). The effect of microwave cooking on the antioxidant properties of the Bangladeshi groundnut cultivar. Acta Sci. Pol. Technol. Aliment., 15, 429-438.

Ali, M. A., Nargis, A., Othman, N. H., Noor, A. F., Sadik, G., Hossen, J. (2016b). Oxidation stability and compositional characteristics of oils from microwave roasted pumpkin seeds during thermal oxidation. Int. J. Food Prop., http://dx.doi.org/10.1080/10942912.2016.1244544

Anjum, F., Anwar, F., Jamil, A., Iqbal, M. (2006). Microwave cookingeffects on the physico-chemical composition 
Li, K. S., Ali, A., Muhammad, I. I. (2017). The influence of microwave cooking on the nutritional composition and antioxidant activity of the underutilized perah seed. Acta Sci. Pol. Technol. Aliment., 16(3), 283-292. http://dx.doi.org/10.17306/J.AFS.2017.0497

and oxidativestability of sunflower seed oil. J. Am. Oil Chem. Soc., 83, 777-784.

AOAC (1990). Official methods of analysis of AOAC international. VA, USA: AOAC International.

Atmani, D., Chaher, N., Berboucha, M., Ayouni, K., Lounis, H., Boudaoud, H., ..., Atmani, D. (2009). Antioxidant capacity and phenol content of selected Algerian medicinal plants. Food Chem., 112, 303-309.

Baba, W. N., Rashid, I., Shah, A., Ahmad, M., Gani, A. Masoodi, F. A., ..., Wani, S. M. (2016). Effect of microwave cooking on antioxidant and anticancerous activities of barley flour. J. Saudi Soc. Agric. Sci., 15, 12-19.

Behera, S., Nagarajan, S., Rao, L. J. M. (2004). Microwave heating and conventional roasting of cumin seeds $(\mathrm{Cu}$ minum cyminum L.) and effect on chemical composition of volatiles. Food Chem., 87, 25-29.

Corner, E. J. H. (1989). Wayside trees of Malaya. Kuala Lumpur, Malaysia: United Selangor Press.

Dicenta, F., Martinez-Gomez, P., Grane, N., Martin, M. L., Leon, A., Canovas, J. A., Berenguer, V. (2002). Relationship between cyanogenic compounds in kernels, leaves, and roots of sweet and bitter kernelled almonds. J. Agr. Food Chem., 50, 2149-2152.

Durmaz, G., Alpaslan, M. (2007). Antioxidant properties of roasted apricot (Prunus armeniaca L.) kernel. Food Chem., 100, 1177-1181.

Durmaz, G., Gökmen, V. (2011). Changes in oxidative stability, antioxidant capacity and phytochemical composition of Pistacia terebinthus oil with roasting. Food Chem., 128, 410-414.

Durmaz, G., Karabulut, I., Topcu, A., Asilturk, M., Kutlu, T. (2010). Roasting-related changes in oxidative stability and antioxidant capacity of apricot kernel oil. J. Am. Oil Chem. Soc., 87, 401-409.

Gutfinger T. (1981). Polyphenols in olive oils. J. Am. Oil Chem. Soc., 58, 966-968.

Herchi, W., Ammar, K. B., Bduali, I., Abdallah, I. B., Guetet, A., Bdukhchina, S. (2016). Heating effects on physicochemical characteristics and antioxidant activity of flaxseed hull oil (Linum usitatissimum L). Food Sci. Technol (Campinas), 36, 97-102.

Husin, N., Tan, N. A. H, Muhamad, I. I., Nawi, N. M. (2013). Physicochemical and biochemical characteristics of the underutilized Elateriospermum Tapos. J. Teknol., 64, 57-61.

Jain, T., Grover, K., Kaur, G. (2016). Effect of processing on nutrients and fatty acid composition of gardencress (Lepidium sativum) seeds. Food Chem., 213, 806-812.

Jau-Tien, L., Shih-Chun, L., Chao-Chin, H., Yung-Shin, S., Chia-Ying, H., Deng-Jye, Y. (2016). Effects of roasting temperature and duration on fatty acid composition, phenolic composition, Maillard reaction degree and antioxidant attribute of almond (Prunus dulcis) kernel. Food Chem., 190, 520-528.

Jogihalli, P, Singh, L. Sharanagat, V. S. (2017). Effect of microwave cooking parameters on functional and antioxidant properties of chickpea (Cicer arietinum). LWT - Food Sci. Technol., 79, 223-233.

Kim, H. G., Kim, G. W., Oh, H., Yoo, S. Y., Kim, Y. O., Oh, M. S. (2011). Influence of roasting on the antioxidant activity of small black soybean (Glycine max L. Merrill). LWT - Food Sci. Technol., 44, 992-998.

Manzocco, L., Calligaris, S., Mastrocola, D., Nicoli, M. C., Lerici, C. R. (2000). Review of non-enzymatic browning and antioxidant capacity in processed foods. Trend Food Sci. Technol., 11, 340-346.

Mariod, A. A., Ahmed, S. Y., Abdelwahab, S. I., Cheng, S. F., Eltom, A. M., Yagoub, S. O., Gouk, S. W. (2012). Effects of roasting and boiling on the chemical composition, amino acids and oil stability of safflower seeds. Int. J. Food Sci. Technol., 47, 1737-1743.

Nanasombat, S., Wimuttigosol, P. (2011). Antimicrobial and antioxidant activity of spice essential oils. Food Sci. Biotechnol., 20, 45-53.

Negro, C., Tommasi, L., Miceli, A. (2003). Phenolic compounds and antioxidant activity from red grape marc extracts. Bioresour. Technol., 87, 41-44.

Ngamriabsakul, C., Kommen, H. (2009). The preliminary detection of cyanogenic glycosides in pra (Elateriospermum tapos Blume) by HPLC. Walailak J. Sci. Tech., 6, 141-147.

Ozdemir, M., Devres, O. (2000). Analysis of colour development during roasting of hazelnuts using response surface methodology. J. Food Eng., 45, 17-24.

Siger, A., Nogala-Kalucka, M., Lampart-Szczapa, E. (2008). The content and antioxidant activity of phenolic compounds in cold pressed plant oils. J. Food Lipid., 15, 137-149.

Summa, C., Raposo, F. C., McCourt, J., Scalzo, R. L., Wagner, K.-H., Elmadfa, I., Anklam, E. (2006). Effect of roasting on the radical scavenging activity of cocoa beans. Eur. Food Res. Technol., 222, 368-375.

Takagi, S., Ienaga, H., Tsuchiya, C., Yoshida, H. (1999). Microwave cooking effects on the composition of tocopherols and acyl lipids within each structural part and section of a soya bean. J. Sci. Food Agri., 79, 1155-1162.

Tenyang, N., Ponka, R., Tiencheu, B., Djikeng, F. T., Azmeera, T., Karuna, M. S. L., ..., Womeni, H. M. (2017). Effects of boiling and roasting on proximate composition, lipid oxidation, fatty acid profile and mineral 
Li, K. S., Ali, A., Muhammad, I. I. (2017). The influence of microwave cooking on the nutritional composition and antioxidant activity of the underutilized perah seed. Acta Sci. Pol. Technol. Aliment., 16(3), 283-292. http://dx.doi.org/10.17306/J.AFS.2017.0497

content of two sesame varieties commercialized and consumed in Far-North Region of Cameroon. Food Chem., 221, 1308-1316.

Wani, I. A., Gani, A., Tariq, A., Sharma, P., Masoodi, F. A., Wani H. M. (2016). Effect of roasting on physicochemical, functional and an properties of arrowhead (Sagittaria sagittifolia L.) flour. Food Chem., 197, 345-352.

Win, M. M., Abdul-Hamid, A., Baharin, B. S., Anwar, F., Saari, N. (2011). Effects of roasting on phenolics composition and antioxidant activity of peanut (Arachis hypogaea L.) kernel flour. Eur. Food Res. Technol., 233, 599-608.
Woffenden, H. M., Ames, J. M., Chandra, S., Anese, M., Nicoli, C. (2002). Effect of kilning on the antioxidant and pro-oxidant activities on pale malt. J. Agric. Food Chem., 50, 4925-4933.

Yong, O. Y., Salimon, J. (2006). Characteristics of Elateriospermum tapos seed oil as a new source of oilseed. Ind. Crop Prod., 24, 146-151.

Zou, Y., Yang, M., Zhang, G., He, H., Yang, T. (2015). Antioxidant activities and phenolic compositions of wheat germ as affected by the roasting process. J. Am. Oil Chem. Soc., 92, 1303-1312. 